DEUIFD LII / 2020, ss. 39-65.

\title{
İLAHİYAT FAKÜLTESİ ÖĞRENCİLERİNİN ÖĞRETMENLİK UYGULAMASI İLE İLGİLİ GÖRÜŞLERİ: DEÜ İLAHİYAT FAKÜLTESİ ÖRNEĞİ
}

\author{
Doç. Dr. Şükrü KEYİFLI*
}

ÖZ

$\mathrm{Bu}$ araştırmanın amac1 meslek öncesinde öğretmen adaylarının öğretmenlik becerilerini geliştirmesini sağlayacak olan öğretmenlik uygulaması derslerine ilişkin görüss ve düşüncelerini öğrenmektir. Araştırmanın evrenini Dokuz Eylül Üniversitesi İlahiyat Fakültesi 2019-2020 öğretim yllı bahar dönemi son sınıf öğrencileri, örneklemini de bu evreninin içinden tesadüfü örneklem yöntemi ile belirlenen 108 öğrenci oluşturmaktadır. Araştırma betimsel niteliklidir. Araştırmada, anket yoluyla elde edilen verilerin IBM SPSS Statistics 22 programında analizi edilmiştir. Yapılan analizler araştırmanın yapısı gereği frekans, yüzdelik ve T Testi isslemleri ile sınırlı tutulmuştur.

Araştırma yapılan analizlerden elde edilen sonuçlara göre örneklem grubunu oluşturan öğrenciler, öğretmenlik uygulaması için gerekli olan, Alan Bilgisi, Alan Eğitimi, Öğretme ve Öğrenme Süreçleri, Sınıf Yönetimi, Etkili İletişim ve Değerlendirme ve Kayıt Tutma bilgi, beceri ve davranışlar bakımından kendilerini yeterli gördüklerini belirtmişlerdir. Anket verilerinden elde edilen bulgulara göre öğrenciler, öğretmenlik uygulaması dersinin, mesleki becerilerin geliştirilmesi için gerekli olduğuna inandıklarını ortaya koymuşlardır.

Anahtar Kelimeler: Öğretmen yetiştirme programı, İlahiyat, Din Kültürü ve Ahlak Bilgisi Öğretmenliği, Öğretmenlik Uygulaması Dersi, Öğretmen Aday1

\section{OPINIONS OF THE FACULTY OF DIVINITY STUDENTS ABOUT TEACHING PRACTICE: EXAMPLE OF DEU FACULTY OF DIVINITY}

\section{ABSTRACT}

The aim of this research is to learn the opinions and thoughts about teacher practice lessons that will enable pre-service teachers to improve their teaching skills. The sample of the research consists of 108 students of Dokuz Eylul University, Faculty of Divinity 2019-2020 academic year, spring semester. The

* Doç. Dr., Dokuz Eylül Üniversitesi, İlahiyat Fakültesi, Din Eğitimi A.B.D, sukru.keyifli@deu.edu.tr, ORCID ID: https://orcid.org/0000-0002-4605- 5205.

Makalenin Hakemlere Gönderiliş Tarihi : 10/07/2020

Makalenin Hakemlerden Geliş Tarihi : 16/10/2020 
research is descriptive. In the analysis of the data obtained in the research, frequency, percentage and $\mathrm{T}$ Tests were used, which are statistical processes.

According to the results obtained from the analysis conducted, the students forming the sample group stated that they considered themselves sufficient in terms of knowledge, skills and behaviors, in the knowledge of the Field, in the education of the Field, Teaching and Learning Processes, Classroom Management, Effective Communication and Evaluation and Record Keeping which are necessary for teaching practice. According to the findings obtained from the questionnaire data, the students confirmed that the teaching practice course is a practice-oriented profession by saying that they believe that the teaching practice course is necessary for the development of professional skills.

Keywords: Teacher training program, Theology, Teaching on Religious Culture and Moral Education, Teaching Practice Course, Prospective Teacher

\section{GİRİŞ}

Türkiye'de öğretmen yetiştirme çalışmalarının tarihi Cumhuriyet öncesine kadar uzanır. Öğretmen yetiştirme çalışmalarıyla ilgili ilk teşebbüs, 1848 yılında Darülmuallimin-i Rüşdî ve 1868 yılındaki Darülmüallimin-i Sıbyan'ın kuruluşu ile başlamıştır. ${ }^{1}$ Eğitim sistemi konusunda kısmen bocalamaların yaşandığ 19. yüzyıl sonlarına rastlayan bu çalışmalar, eğitim ile ilgili iyileştirme çalışmalarının, ilk iş olarak öğretmen yetiştirme ile olacağına inanıldığını göstermektedir.

Eğitim sisteminin iyileştirilmesi ve öğretmen yetiştirme sorunu, Cumhuriyetin ilanından sonraki dönemde de devam etmiştir. Bu bağlamda, Cumhuriyetle birlikte eğitimde ilk önemli adımın, Tevhid-i Tedrisat ile atıldığı söylenebilir. Bu adımın içinde doğrudan olmasa bile dolaylı olarak öğretmen yetiştirme amacı/ programı da bulunmaktadır. Tevhid-i Tedrisatın eğitim ile ilgili tüm faaliyetlerinin Milli Eğitim Bakanlığ1 çatısı altında toplamış olması, öğretmen yetiştirme çalışmaları konusunu da kapsadığını göstermektedir² .

1 Akyüz, Yahya.. "Türk Eğitim Tarihi". Ankara Üniversitesi Eğitim Bilimleri Fakültesi Yayınlar. (1997)

2 Akyüz, Yahya.. "Türk Eğitim Tarihi". Ankara Üniversitesi Eğitim Bilimleri Fakültesi Yaymlar. (1997) 
Cumhuriyetle birlikte bir meslek olarak tanımlanan öğretmenlik, 22 Mart 1926 tarihinde çıkarılan 789 sayılı Maarif teşkilatına dair Kanuna göre (Madde 12) "maarif hizmetlerinde asıl olan muallimliktir" denilerek, eğitim sisteminin merkezine öğretmenin yerleştirilmesi meselesinin oturtulması sağlanmıştır. ${ }^{3}$

Profesyonel bir meslek olan öğretmenliğin, her meslekte olduğu gibi yeterliklerinin de belirlenmesi gerekmekteydi. 1973 yilında TBMM'de kabul edilen 1789 sayılı Milli Eğitim Temel Kanununun 43. maddesinde yeterlikler, "Genel Kültür", "Özel Alan" ve "Pedagojik Formasyon" olarak belirlenmiştir. Söz konusu yeterlikler, günümüzde de Milli Eğitim Bakanlığ1 tarafindan öğretmen olmanın ön şartı olarak kabul edilmektedir. $\mathrm{Bu}$ nedenle öğretmen adaylarının hizmet öncesi eğitimlerinde yer almaktadır. ${ }^{4}$

Günümüzde Türkiye'de eğitim sisteminden beklenilen verimin yeterince alınamamış olduğuna yönelik tartışmaları yapılıyor olması, nitelikli öğretmen yetiştirme ile ilgili arayışları hızlandırmıştır. ${ }^{5} \mathrm{Bu}$ arayışların içinde, hizmet öncesi öğretmen yetiştirme konusu da ağırlıklı olarak yer almaktadır. Milli Eğitim Bakanlığı tarafından hazırlanan "20172023 Öğretmen Yetiştirme ve Geliştirme Strateji Belgesi” ve "2023 Eğitim Vizyon Belgesi”nin yayınlanmış olması, bu arayışların somut yansımaları olarak değerlendirilebilir. ${ }^{6}$ Her iki belge de de vurgulanmak istenen hususların başında, "nitelikli öğretmen"in yetiştirilmesi için gerekli olan "öğretmen nitelikleri”"nin belirlenmesi bulunmaktadır.

Öğretmen niteliklerinden biri de öğretmenlerde bulunması gereken "pedagojik formasyon yeterliğidir. Pedagojik formasyon yeterliğini kazandıran dersler, "Eğitim Bilimlerine Giriş", "Gelişim

\footnotetext{
Akyüz, Yahya.. "Türk Eğitim Tarihi". Ankara Üniversitesi Eğitim Bilimleri Fakültesi Yaymlar. (1997)

4 Dursunoğlu, H. "Cumhuriyet Döneminde İlköğretime Öğretmen Yetiştirmenin Tarihi Gelişimi" . Milli Ë̆gitim Dergisi, (2003):64-74.

5 Bulut, İlhami.. "Öğretmen Adaylarının Öğretmenlik Mesleğine İlişkin Tutumlarının Değerlendirilmesi" . Dicle Üniversitesi Ziya Gökalp Eğitim Fakültesi Dergisi, (2009): 13 24.

6 Üstüner, Mehmet. "Geçmişten Günümüze Türk Eğitim Sisteminde Öğretmen Yetiştirme ve Günümüz Sorunlar1". İnönü Üniversitesi Eğitim Fakültesi Dergisi, (2004):63-82.
} 
Psikolojisi”, "Öğrenme ve Öğretme Kuram ve Yaklaşımları", "Program Geliştirme ve Öğretim”, "Sınıf Yönetimi, "Rehberlik", "Ölçme ve Değerlendirme", "Öğretim Teknolojileri ve Materyal Geliştirme”, "Özel Öğretim Yöntemleri” ve "Öğretmenlik Uygulaması" dersleridir. Aralarında, "Özel Öğretim Yöntemleri”, “Öğretim Teknolojileri ve Materyal Tasarımı" ve "Öğretmenlik Uygulaması" gibi uygulama dersleri de vardır. Özellikle öğretmenlik Uygulaması Dersi, öğretmenlik becerilerinin hayata geçirildiği yegâne ders olması bakımından önemlidir. ${ }^{8}$

Öğretmenlik uygulaması dersi ile ilgili yapılan araştırmalar, konuyla ilgili alanın tanınmasına katkı sağlamaktadır. Yapılan araştırmalarda değişik problem cümleleri oluşturulmuş ve konuyla ilgili hipotezler geliştirilmiştir. Bu problemlerden biri de öğretmen adaylarının meslek öncesi eğitimlerinde almış oldukları eğitimin teori ve uygulama bütünlügüunün sağlanıp sağlanmadığının bilinmesidir. Bu çalışmadan elde edilen sonuçlara göre uygulamaya giden öğrencilerin almış oldukları teorik bilgilerin öğretmenlik uygulaması dersi ile ilgili etkinlikleri yerine getirebilmeleri bakımından yeterli olduğu, bu bilgileri uygulama ortamında beceriye dönüştürdükleri ve alan eğitiminde kendilerini daha da geliştirdikleri tespit edilmiştir. ${ }^{9}$

Bir başka araştırmada ise, Öğretmenlik Uygulaması dersi ile ilgili sürecin yönetilmesinde, danışman öğretmenlerin ve öğretim elemanlarının görüş ve düşüncelerinin bilinmesi istenmiştir. Konuyla ilgili yapılan bir araştırmada, danışman öğretmenler ve danışman öğretim elemanları, öğretmen adayı öğrencilerinin meslek öncesi eğitimlerinde Öğretmenlik Uygulaması dersinin, öğrencilerin mesleki bakımdan

7 Şeyihoğlu, Ayşegül., \& Duman, Neşe. "Özel Ö̆gretim Yöntemleri Dersinin Pedagojik Formasyon Eğitimi Çoğrafya Bölümü Öğrencileri Açısından Bakış". Kastamonu Eğitim Dergisi, (2020): 442-456.

8 Nayır, F., \& Çınkır, Ş. "Uygulama Öğretmenleri, Yöneticileri ve Pedagojik Formasyon Öğrencilerinin Okullarda Öğretmenlik Uygulamasında Karşılaştıklanı Sorunlar ve Çözüm Önerileri." Uluslararsı Eğitim Programlar ve Öğretim Calışmalar Dergisi, (2014): 71-86.

9

Karadüz , Adnan., Eser, Yusuf., Şahin , C.emil, \& İlbay, Azmi." Eğitim Fakültesi Son Sınıf Öğrencilerinin Görüşlerine Göre Öğretmenlik Uygulaması Dersinin Etkinlik Düzeyi." Mustafa Kemal Üniversitesi Sosyal Bilimler Enstitüsü Dergisi , (2009):442-455. 
yetişmelerinde olumlu etkisinin olduğunu gözlemlediklerini ifade etmişlerdir..$^{10}$

Öğretmenlik Uygulaması dersinin, öğretmen adaylarına meslek öncesi eğitimlerinde bilgi, beceri, uygun tutum ve davranışların kazandırılmasında olumlu etkisi vardır. Öğretmenlik Uygulaması dersinin öğretmen adaylarının, mesleki bakımdan yetişmesinde çok olumlu etkisinin olduğu, ayrıca fakülte ve uygulama okulları arasındaki iletişim ve işbirliği düzeyinin artırılmasında olumlu etkisinin bulunduğu tespit edilmiştir. ${ }^{11} \mathrm{Bu}$ işbirliğinin geliştirilmesinde fakülte-okul yöneticileri, öğretmenler ve öğretim üyeleri arasında bilgi alış verişinin yapılması öncelikle ele alınması gereken bir husustur. ${ }^{12}$

Öğretmen adayları öğretmenlik uygulaması ile ilgili deneyimleri sırasında bazı problemlerle karşılaşmaktadırlar. Öğrencilerin, öğretmenlik uygulaması yaptıkları okullarda bazı sorunlarla karşılaştıklarını, bu sorunların cinsiyete göre farklılıklar gösterdiği tespit edilmiştir. Buna göre kız öğrencilerin erkek öğrencilere göre daha fazla sorun yaşadıkları, yapılan araştırmanın sonuçlarından biridir. ${ }^{13}$

Din Kültürü ve Ahlak Bilgisi, İmam-Hatip Meslek Dersleri öğretmenlerinin, Öğretmenlik Uygulaması dersinin hizmet öncesinde ögretmenlik konusunda gerekli olan yeterlik duygusuna sahip olmaları ve ögrretmenlikle ilgili bilgi, beceri ve tutumların yerine getirilmesinde öz güven sahibi olabilmeleri bakımından önemli bir derstir. İlahiyat

10 Görgen, İzzet., Çokçalışkan, Halil, \& Korkut, Ünsal. "Öğretmenlik Uygulaması Dersinin Öğretmen Adaylan Uygulam Öğretmenleri ve Uygulama Öğretim Üyeleri Açısından İşlevselliği". Muğla Üniversitesi Sosyal Bilimler Enstitüsü Dergisi , (2012).5672.

Kılıç, Durmuş."Öğretmenlik Uygulaması Dersinin Öğretmen Adayları Üzerine Etkisinin Değerlendirilmesi" . Ką̧ım Karabekir Eğitim Fakültesi Dergisi , (2004):172184. Üniversitesi Eğitim Fakültesi Dergisi , (2003): 87-100.

13 Demir, Özden \& Çaml, Özgül. "Öğretmenlik Uygulaması Dersinde Uygulama Okullarında Karşılaşılan Sorunların Sınıf ve Okul Öncesi Öğretmenliği Öğrenci Görüşleri Çerçevesinde İncelenmesi: Nitel Bir Çalışma ". Uludăg Üniversitesi Eğitim Fakülttesi Dergisi, (2011): 117-139. 
fakültelerinin ilahiyat lisans bölümünden 1997 yllında "pedagojik formasyon" derslerinin kaldırılmış olması kısmen de olsa öğrencilerde öğretmenlikle ilgili bir ideal eksikliğine neden olduğu tahmin edilmektedir. Bu eksiklik, öğretmenlik mesleği ile ilgili gerek sınıf içi teorik gerek öğretmenlik uygulaması dersinin yürütülmesinde kısmen özgüven kaybına sebep olduğu söylenebilir. Bu kaybın hangi düzeyde olduğunun bilinmesi, öğrencilerin öğretmenlik mesleğine karşı tutumları bakımından önemlidir.

Çalışma, Dokuz Eylül Üniversitesi İlahiyat Fakültesi son sınıfında öğrenim görmekte olan öğrencilerin bir başka deyişle Din Kültürü ve Ahlak Bilgisi ve İmam- Hatip Lisesi Meslek dersleri öğretmeni adaylarının "Öğretmenlik Uygulaması Dersi" ile ilgili uygulama becerilerini yerine getirme konusundaki görüşlerinin öğrenilmesi amacıyla yapılmıştır. Bu genel amaç çerçevesinde aşağıdaki iki temel soruya cevap aranmıştır. (1). Öğretmen adaylarının öğretmenlik uygulaması dersi ile ilgili görüşleri nedir? (2). Cinsiyet değişkenine göre anlamlı bir farklılık göstermekte midir?

\section{Problem Cümlesi}

İlahiyat Fakültesi son sınıf öğrencileri, öğretmenlik uygulaması dersi için gerekli olan mesleki bilgi ve becerileri konusunda yeterli olduklarını düşünüyorlar mı?

\section{Alt Problemler}

İlahiyat Fakültesi öğrencileri, öğretmenlik uygulamasını yerine getirmek konusunda bilgi, beceri ve davranışlara sahip olduklarını düşünmekte midirler?

1. Öğretmenlik alan bilgisi ile ilgili temel ilke ve kavramları bilme konusunda kendilerini yeterli görüyorlar mı?

2. Din Kültürü ve Ahlak Bilgisi dersi alan eğitimi ile ilgili sahip olunması gereken öğretim yeterliklerine sahip olduklarını düşünüyorlar mi?

3. Öğrenciler, öğretmenlik uygulaması için gerekli olan öğrenme ve öğretme süreçleri hakkında yeterli bilgi beceri ve davranışlara sahip olduklarını düşünüyorlar mı? Bu bağlamda dersin planlanmasını, 
uygulanmasını ve değerlendirmesini yapabilme konusunda kendilerine güvenmekte midirler?

4. Öğrenciler, sınıf içi öğretim sürecinin yönetimi ve sürdürülmesi ile ilgili gerekli olan bilgi, beceri ve davranışlara sahip olduklarına inaniyorlar mi?

5. Öğrenciler, öğretmenlik uygulaması sırasında sınıf içinde ve dışında öğrencilerle etkili iletişim kurabileceklerine inanıyorlar mı?

\section{Varsayımlar}

1. Ankete katılarak örneklem grubunu oluşturan öğrenciler, görüşlerini belirtirken yeterince istekli oldukları kabul edilmiştir.

2. Ankette kullanılan ölçek maddeleri, yapılan araştırmanın konusunu kapsayacak nitelikte olduğu kabul edilmiştir.

\section{Sinirliliklar}

1. Bu araştırma 2019-2020 öğretim y1lında Dokuz Eylül Üniversitesi İlahiyat Fakültesi 4. Sınıf öğrencilerini kapsamaktadır.

2. Araştırma bu fakültede yer alan yüz yüze öğretim ( örgün öğretim) öğrencileri ile sinırlıdır.

\section{Yöntem}

Araştırmada, nicel araştırma modeli kullanılmıştır. Araştırmada kullanılan anket soruları "Öğretmenlik Uygulaması Değerlendirme Forumu'ndaki ölçme maddelerinden elde edilmiştir. Veri elde etme çalışmalarında bu anket sorularının geçerlik ve güvenilirlik ön çalışması yapılmış ve yapılan ölçümde Güvenilirlik çalışmasında Alpha değeri 0,94 olarak hesaplanmıştır. Yapılan ölçüm sonucunda elde edilen bu sonuca göre araştırmanın yüksek düzeyde güvenilir olduğu görülmüştür. Google Form üzerinden geliştirilen anket formları, öğrencilerle yapılan ön görüşmeden sonra izinleri alınarak elektronik postalarına ilgili formun linki gönderilmiştir. Google Form üzerinden toplanan veriler IBM SPSS Statistics 22 ile analiz edilmiştir.

\section{Evren ve Örneklem}

Araştırmanın evreni Dokuz Eylül Üniversitesi İlahiyat Fakültesi 4. Sınıf öğrencilerini kapsamaktadır. 
Araştırmanın örneklemini 2019-2020 öğretim y1lında Dokuz Eylül Üniversitesi İlahiyat Fakültesi 4. Sınıf öğrencilerinin 3 aylık süre içinde Google Form üzerinden anketi doldurarak geri dönüş yapan öğrenciler oluşturmuştur.

\section{Veri Toplama Araci}

Araştırmada veri toplama aracı olarak "Öğretmenlik Uygulaması Değerlendirme Formundaki maddelerin içinden 40 tanesi kullanılmıștır. Kullanılan soru maddeleri kullanilan "Konu Alanı Alt Problemi”, "Alan Eğitimi Bilgisi Alt Problemi", "Öğretme Sürecini "Planlama Alt Problemi", "Sınıf Yönetimi Alt Problemi" ve "İletişim Becerileri Alt Problemi olmak üzere, toplam altı alt boyuttan oluşmaktadır. Anket maddelerine ilişkin görüşler beşli likert ölçeğine dayanmaktadır.

\section{Verilerin Analizi}

Veri toplama kullanılan anketlerden elde edilen bilgiler bilgisayar ortamına aktarılarak IBM SPSS Statistics 22 programıyla analiz edilmiştir. Yapılan analizlerde veriler arasındaki ilişkiler tespit edilerek tablolar haline getirilmiştir. Ankete katılan öğrencilerin cinsiyet ve yaş bağımsız değişkeni ile sürekli değişkenler arsındaki ilişkinin tespit edilmesi için frekans ve betimsel İstatistik değerleri yanında ankete katılanlarla ilgili kategorik değişkenlerin hesaplanması için gerekli olan " Bağımsız Gruplar T Testi yapılmıştır. Çıkan sonuçlar anlamlılık düzeyleri belirlenerek tablolar halinde sunulmuştur.

\section{BULGULAR VE YORUM}

Bu başlık altında araştırmada elde edilen bulgular tablolar halinde gösterilmiştir. Bu bağlamda, ankete katılan öğrenciler ile ilgili demografik bilgiler, Konu Alanı, Alan Eğitimi, Öğretme ve Öğrenme Süreci, Sınıf Yönetimi, İletişim ve Kayıt Tutma ve Değerlendirme alt problemleri ile ilgili ölçek maddelerine ilişkin istatistik değerleri yer almaktadır. Ayrıca örneklem grubu öğrencilerinin ankete verdikleri bilgilerde cinsiyete durumuna göre aralarında anlamlı bir farkın olup olmadığını ölçen " $t$ Testi" sonuçları da tablolar halinde yer almaktadır. 
1. Öğrencilere ait demografik bilgiler

\section{1. Cinsiyet İle İlgili Bilgiler}

Tablo 1. Cinsiyet Durumu İle İlgili Bilgiler

\section{Cinsiyet Durumu}

\begin{tabular}{|c|c|c|c|c|}
\hline & $\mathrm{F}$ & $\%$ & $\begin{array}{l}\text { Geçerli } \\
\%\end{array}$ & $\begin{array}{l}\text { Toplam } \\
\%\end{array}$ \\
\hline Kadin & 60 & 55,6 & 55,6 & 55,6 \\
\hline Erkek & 48 & 44,4 & 44,4 & 100,0 \\
\hline Toplam & 108 & 100,0 & 100,0 & \\
\hline
\end{tabular}

Tablo 1'e göre öğretmenlik uygulaması ile ilgili araştırmaya Dokuz Eylül Üniversitesi İlahiyat Fakültesi son sinıf öğrencilerinden toplam 108 öğrenci katılmıştır. Buna göre katılımcıların 60'ı'nı kız öğrenciler (\% 55.6), 48’ini erkek öğrenciler (\% 44.4) oluşturmaktadır.

\section{2. Yaş Durumu}

Tablo 2. Yaş Durumu İle İlgili Bilgiler

\section{Yaş Durumu}

\begin{tabular}{ccccc}
\hline \hline & F & $\%$ & Geçerli \% & Toplam \% \\
\hline 20-25 Yaş Arası & 93 & 86,1 & 86,1 & 86,1 \\
26-30 Yaş Arası & 9 & 8,3 & 8,3 & 94,4 \\
31- 35 Yaş Arası & 2 & 1,9 & 1,9 & 96,3 \\
36-35 Yaş Arası & 4 & 3,7 & 3,7 & 100,0 \\
Toplam & 108 & 100,0 & 100,0 & \\
\hline \hline
\end{tabular}


Tablo 2'de de görüldüğü gibi ankete katılan öğrencilerin çoğunluğunu 93 öğrenci $(\%$ 86.1) ile $20-25$ yaş arasındakiler oluşturmaktadır. Arkasından az sayıda da olsa 9 öğrenci (\% 8.3) ile 26-30 yaş aralı̆̆ındaki öğrenciler oluşturmaktadır. Buna göre son sinıfta öğrenim görmekte olan öğrencilerin çoğunluğunun dönem ya da yıl kayb1 olmadan mezun durumuna gelmiş oldukları anlaşılmaktadır.

\section{2. Öğretmenlik Uygulamasına İlişkin Görüşlerin Dağılım}

\section{Tablosu}

Bu tabloda, araştırmada veri toplama aracı olarak kullanılan ölçek maddeleri ve bu ölçeklere cevap verenlerin sayıları, en düşük ve en yüksek puan değerleri, aritmetik ortalamaları ile standart sapma verileri yer almaktadir.

Tablo 2. Ölçekle İlgili Betimsel Analiz Sonuçları

Betimsel İstatistik Sonuçları

\begin{tabular}{lccccc}
\hline \hline MADDELER & $\mathrm{N}$ & $\mathrm{Min}$ & Max. & $\mathrm{X}$ & $\mathrm{SS}$ \\
\hline M1 & 108 & 2 & 5 & 3,96 &, 995 \\
M2 & 108 & 2 & 5 & 3,92 &, 699 \\
M3 & 108 & 1 & 5 & 3,93 &, 883 \\
M4 & 108 & 3 & 5 & 3,96 &, 709 \\
M5 & 108 & 3 & 5 & 3,59 &, 737 \\
M6 & 108 & 3 & 5 & 4,14 &, 779 \\
M7 & 108 & 1 & 5 & 3,83 &, 743 \\
M8 & 108 & 3 & 5 & 3,74 &, 753 \\
M9 & 108 & 3 & 5 & 4,04 &, 760 \\
M10 & 108 & 1 & 5 & 3,95 &, 961 \\
M11 & 108 & 3 & 5 & 4,19 &, 716 \\
M12 & 108 & 1 & 5 & 3,83 &, 779 \\
M13 & 108 & 3 & 5 & 3,94 &, 727 \\
M14 & 108 & 3 & 5 & 3,88 &, 758
\end{tabular}


İlahiyat Fakültesi Ögrrencilerinin Öğretmenlik Uygulaması İle İlgili Görüsleri

\begin{tabular}{llllll} 
M15 & 108 & 3 & 5 & 4,30 &, 645 \\
M16 & 108 & 3 & 5 & 3,93 &, 770 \\
M17 & 108 & 1 & 5 & 3,74 &, 825 \\
M18 & 108 & 3 & 5 & 4,14 &, 755 \\
M19 & 108 & 1 & 5 & 3,73 &, 892 \\
M20 & 108 & 3 & 5 & 3,86 &, 803 \\
M21 & 108 & 3 & 5 & 4,17 &, 717 \\
M22 & 108 & 3 & 5 & 3,90 &, 710 \\
M23 & 108 & 3 & 5 & 4,15 &, 695 \\
M24 & 108 & 1 & 5 & 4,11 &, 789 \\
M25 & 108 & 1 & 5 & 4,06 &, 812 \\
M26 & 108 & 1 & 5 & 3,69 &, 839 \\
M27 & 108 & 1 & 5 & 3,69 &, 719 \\
M28 & 108 & 1 & 5 & 3,89 &, 801 \\
M29 & 108 & 1 & 5 & 4,09 &, 743 \\
M30 & 108 & 3 & 5 & 4,33 &, 670 \\
M31 & 108 \\
M32 & 108 & 1 & 5 & 4,06 &, 795 \\
M33 & 108 & 3 & 5,30 &, 714 \\
M34 & 108 & 3 & 5 & 4,19 &, 686 \\
M35 & 108 & 3 & 5 & 4,13 &, 762 \\
M36 & 108 & 3 & 5 & 4,04 &, 842 \\
M38 & 3 & 5 & 4,48 &, 662 \\
\hline M40 & 3 & 5 & 3,10 &, 875 \\
\hline & 108 & 5,80 &, 794 \\
M39 & 3 & 5,94 &, 740 \\
\hline & 108 & 5475 \\
\hline
\end{tabular}


Örneklem grubunu oluşturan katılımcılardan elde edilen verilere göre tablo 3'de görüldüğü gibi ölçek maddelerine verilen cevapların puan ortalama değerlerinin en düşük olanı $\mathrm{X}=3.59$ ile "M5" olurken, en yüksek ortalama değeri alan ölçek $X=4,48$ ile M36 ölçeği olmuştur. Yapılan ölçümün sonucunda, tüm ölçeğin aritmetik ortalamalarının yaklaşık 3.5 ile 4.5 arasında çıkmıs olması, ankete katılan öğrencilerin, öğretmenlik uygulaması ile ilgili yeterlikler konusunda, kendilerini hazır bulduklarını göstermektedir. Bu sonuçlara göre öğrencilerin genel olarak, öğretmenlik uygulaması için katılmak durumunda oldukları okul ve sınıf öğretim sürelerini yönetme konusunda güven içinde oldukları anlaşılmaktadır.

\section{3. Öğretmenlik Uygulaması Ölçeği Alt Problemi}

Bu başlık altında, "Konu Alanı Alt Problemi”, “ Alan Eğitimi Alt Problemi”, “ Öğrenme Öğretme Süreci Alt Problemi”, Sınıf Yönetimi Alt Problemi", ve "İletişim Alt Problemi” yer almaktadır. Ölçeğin içindeki maddelerin muhtevasina göre tasnif edilmiş olan bu alt boyutlar, araştırmaya katılan öğrencilerin öğretmenlik uygulaması ile ilgili görüş ve düşüncelerini yansıtacak muhtevadadır.

\section{1. Konu Alanı Alt Problemi}

Konu alanı alt Problemi toplam dört ölçek maddesinden oluşmaktadır. Bu maddeler,1, 2, 3, 4, numaralı ölçekleri oluşturmaktadır.

Tablo 3. Konu Alanı Alt Problemi İle İlgili İstatistik Değerler

\begin{tabular}{lllllllllll}
\hline \hline & $\begin{array}{l}\text { 1.Hiç } \\
\text { Emin } \\
\text { Değilim }\end{array}$ & 2.Emin & 3eğilim & 3. Emin & 4.Eminim & \multicolumn{2}{l}{$\begin{array}{l}\text { 5. Oldukça } \\
\text { Eminim }\end{array}$} \\
\hline \hline & $\mathrm{N}$ & $\%$ & $\mathrm{~N}$ & $\%$ & $\mathrm{~N}$ & $\%$ & $\mathrm{~N}$ & $\%$ & $\mathrm{~N}$ & $\%$ \\
$\mathrm{M} 1$ & - & - & 2 & 1,9 & 49 & 45,4 & 8 & 7,4 & 49 & 45,4 \\
M2 & - & - & 2 & 1,9 & 25 & 23,1 & 61 & 56,5 & 20 & 18,5 \\
M3 & 1 & 0,9 & 5 & 4,6 & 25 & 23,1 & 47 & 43,5 & 30 & 27,8 \\
\hline M4 & - & - & - & - & 29 & 26,9 & 54 & 50,0 & 25 & 23,1 \\
\hline
\end{tabular}

Tabloda görüldüğü gibi ankete katılan öğrencilerin çoğunluğu ölçekte 3. numara ile yer alan ve "emin gibiyim" şeklindeki ifadeyi tercih 
etmisslerdir. Buna göre katılımcılar, konu alan bilgisi ile ilgili bazı eksikliklerinin olduğunu kabul etmektedirler.

\section{2. Alan Eğitimi Alt Problemi}

Alan eğitimi alt probleminde yer alan ölçek maddeleri, öğretmenlik uygulaması ölçek maddeleri içinde yer alan 5, 6, 7, 8, 9 numaralı maddelerdir. İstatistiği

Tablo 4. Alan Eğitimi İle İlgili Sürekli Değişkenlerin Betimsel

\begin{tabular}{|c|c|c|c|c|c|c|c|c|c|c|}
\hline & \multicolumn{2}{|c|}{$\begin{array}{l}\text { 1. Hiç } \\
\text { Emin } \\
\text { Değilim }\end{array}$} & \multicolumn{2}{|c|}{$\begin{array}{l}\text { 2.Emin } \\
\text { Değilim }\end{array}$} & \multicolumn{2}{|c|}{$\begin{array}{l}\text { 3. Emin } \\
\text { Gibiyim }\end{array}$} & \multicolumn{2}{|c|}{ 4.Eminim } & \multicolumn{2}{|c|}{$\begin{array}{l}\text { 5. Oldukça } \\
\text { Eminim }\end{array}$} \\
\hline & $\mathrm{N}$ & $\%$ & $\overline{\mathrm{N}}$ & $\%$ & $\overline{\mathrm{N}}$ & $\%$ & $\mathrm{~N}$ & $\%$ & $\overline{\mathrm{N}}$ & $\%$ \\
\hline M5 & - & - & - & - & 60 & 55,6 & 32 & 29,6 & 16 & 14,8 \\
\hline M6 & - & - & - & - & 26 & 24,1 & 41 & 38,0 & 41 & 38,0 \\
\hline M7 & 1 & 0,9 & - & - & 34 & 31,5 & 54 & 50,0 & 19 & 17,6 \\
\hline M8 & - & - & - & - & 48 & 44,4 & 40 & 37,0 & 20 & 18,5 \\
\hline M9 & & & & & 29 & 26,9 & 46 & 42,6 & 33 & 30,6 \\
\hline
\end{tabular}

Tablo değerleri incelendiğinde, görüleceği gibi örneklem grubunu teşkil eden öğrenciler, alanlarıyla ilgili özel öğretim yapabilme konusunda kendilerine güvendiklerini ifade etmektedirler. Bunla birlikte, öğretim teknolojilerinden yararlanma, özel öğretim yöntem ve teknikleri ile ilgili yaklaşımlar konusunda ise az da olsa tereddüt yaşadıklarını belirtmişlerdir.

Tablo değerlerine göre öğrencilerin, alan eğitimi ile ilgili alt problem, problemin içinde yer alan ölçek maddeleri bakımından, ortalama puan değerinin pozitif yönde olduğunu söylemek mümkündür.

Yapılan bu istatistiksel analize göre, ankete katılan öğrencilerin öğretmenlik uygulaması sürecinde sınıf içi uygulamalarda yapacak oldukları öğretim etkinlikleri ile ilgili özel öğretim yeterliklerine sahip oldukları söylenebilir. 


\section{3. Öğretme ve Öğrenme Süreci Alt Problemi}

Öğretme ve öğrenme sürecinin içeriğinde bulunan ölçek maddeleri iki başlık altında tasnif edilmiştir. Bunlardan biri "Planlama" diğeri de "Öğretim Sürecidir". Araştırmanın verilerinin toplanmasında örneklem grubuna yöneltilen 10,11, 12, 13, 14, 15. maddeler planlama, $16,17,18,19,20,21,22,23$ numaralı ölçek maddeleri de öğretim süreci ile ilgilidir. İstatistikler

Tablo 5. Öğretme ve Öğrenme Süreci İle ilgili Betimsel

Planlama

\begin{tabular}{|c|c|c|c|c|c|c|c|c|c|c|}
\hline & \multicolumn{2}{|c|}{$\begin{array}{l}\text { 1. Hiç } \\
\text { Emin } \\
\text { Değilim }\end{array}$} & \multicolumn{2}{|c|}{$\begin{array}{l}\text { 2.Emin } \\
\text { Değilim }\end{array}$} & \multicolumn{2}{|c|}{$\begin{array}{l}\text { 3. Emin } \\
\text { Gibiyim }\end{array}$} & \multicolumn{2}{|c|}{ 4.Eminim } & \multicolumn{2}{|c|}{$\begin{array}{l}\text { 5. Oldukça } \\
\text { Eminim }\end{array}$} \\
\hline & $\mathrm{N}$ & $\%$ & $\mathrm{~N}$ & $\%$ & $\mathrm{~N}$ & $\%$ & $\mathrm{~N}$ & $\%$ & $\mathrm{~N}$ & $\%$ \\
\hline M10 & 4 & 3,7 & - & - & 28 & 25,9 & 41 & 38,0 & 35 & 32,4 \\
\hline M11 & - & - & - & - & 19 & 17,6 & 49 & 45,4 & 40 & 37,0 \\
\hline M12 & 1 & 0,9 & - & - & 37 & 34,3 & 48 & 44,4 & 22 & 20,4 \\
\hline M13 & - & - & - & - & 32 & 29,6 & 51 & 47,2 & 25 & 23,1 \\
\hline M14 & - & - & - & - & 38 & 35,2 & 45 & 41,7 & 25 & 23,1 \\
\hline M15 & - & - & - & - & 11 & 10,2 & 54 & 50,0 & 43 & 39,8 \\
\hline \multicolumn{11}{|c|}{ ÖĞRETME VE ÖĞRENME SÜRECİ } \\
\hline M16 & - & - & - & - & 36 & 33,3 & 44 & 40,7 & 28 & 25,9 \\
\hline M17 & 2 & 1,9 & - & - & 42 & 38,9 & 44 & 40,7 & 20 & 18,5 \\
\hline M18 & - & - & - & - & 24 & 22,2 & 45 & 41,7 & 39 & 36,1 \\
\hline M19 & 2 & 1,9 & - & - & 49 & 45,4 & 31 & 28,7 & 26 & 24,1 \\
\hline M20 & - & - & - & - & 43 & 39,8 & 37 & 34,3 & 28 & 25,9 \\
\hline M21 & - & - & - & - & 20 & 18,5 & 50 & 46,3 & 38 & 35,2 \\
\hline M22 & - & - & - & - & 33 & 30,6 & 53 & 49,1 & 22 & 20,4 \\
\hline M23 & - & - & - & - & 19 & 17,6 & 54 & 50,0 & 35 & 32,4 \\
\hline
\end{tabular}


Tablo verilerine göre ankete katılan öğrencilerin, öğretmenlik uygulaması deneyimi için gerekli olan "Ders planını açık, anlaş11ır ve düzenli biçimde yazabilme" konusunda yeterli oldukları anlaşılmaktadır. Tablo 5'de görüldüğü gibi ankete katılan öğrencilerden 41 kişi (\% 38, 0), emin olduklarını, 35 kişi $\left(\begin{array}{l}\% \\ \%\end{array} 2,4\right)$ de oldukça emin olduklarını belirtmişlerdir.

Öğrenciler, dersin giriş davranışlarından biri olan amaç ve hedeflerden haberdar etme konusundaki gerekleri yerine getireceklerine güvenmektedirler. Bu konuda, ankete katılan öğrencilerden 49 kissi (\% 45,4) emin olduklarını, 40 kişi $(\% 37,0)$ de oldukça emin olduklarını ifade etmişlerdir. Öğrencilerden, "hedef davranışları uygun yöntem ve teknikleri belirleyebilirim" diye görüş bildirenlerin 37'si (34,3) kesin olmamakla birlikte yine de yapabileceklerini, 48'i $(44,4)$ dersin girişinde öğrencileri, amaç ve hedefler konusunda gerekli bilgilendirmeyi yapabileceklerinden emin olduklarını, 22' si de oldukça emin olduklarını belirtmişlerdir.

Ankete katılan öğrenciler, derste "Uygun araç-gereç ve materyal seçme ve hazırlayabilme" ile ilgili konularda da kendilerine güvendiklerini ifade etmişlerdir. Katılimcılardan 32 kişi (\% 29,6), yapabilecekleri konusunda fazla zorlanmayacaklarını, 51 kişi $(\% 47,2)$ yapacaklarına inandıklarını ve 25 ' $(\% 23.1)$ de dersin uygulaması sürecinde gerekli olan ve uygun olan materyalleri seçme ve hazırlamada problem yaşamayacaklarını ifade etmişlerdir.

Örneklem grubunu oluşturan öğrenciler, öğretme ve öğrenme süreci alt problemi ile ilgili ölçek maddelerinin nerdeyse tamamina yakınının, 1 ve 2 numaralı ölçek maddelerine cevap vermemiş olmaları, uygulama eğitimi yeterlikleri kazandıran bilgi, beceri ve davranışlar konusunda, fakültede almış oldukları genel öğretim bilgisi eğitimi sürecinin yeterlik kazandırıcı nitelikte olduğunu göstermektedir. Bununla birlikte gerek planlama ve gerekse öğretme öğrenme süreci ile ilgili konularda, deneyim eksikliğinden kaynaklanan bazı tereddütlerinin olduğunu da beyan etmişlerdir (Bkz. Tablo 5)

\section{4. Sinıf Yönetimi Alt Problemi}

Sinıf yönetimi alt problemi içinde ölçekte yer alan 24, 25, 26, 27, $28,29,30,31$ ve 32 numaralı ölçek maddeleri bulunmaktadır. Bu maddeler de ders başında, ders sırasında ve ders sonunda olmak üzere üç aşamalı bir süreç yönetimini kapsamaktadır. Her bir süreç ile ilgili 
yapılması gerekenler, öğretmenlik uygulaması değerlendirme formundaki yeterlik maddelerinden oluşturulmuştur. Ankete katılan öğrencilerin, bu yeterlikler konusundaki görüşleri tablo 6'da yer almaktadır.

İstatistikler

Tablo 6. Sinıf Yönetimi Alt Problemi İle ilgili Betimsel DERS BASSINDA

\begin{tabular}{|c|c|c|c|c|c|c|c|c|c|c|}
\hline & \multicolumn{2}{|c|}{$\begin{array}{l}\text { 1. Hiç } \\
\text { Emin } \\
\text { Değilim }\end{array}$} & \multicolumn{2}{|c|}{$\begin{array}{l}\text { 2.Emin } \\
\text { Değilim }\end{array}$} & \multicolumn{2}{|c|}{$\begin{array}{l}\text { 3. Emin } \\
\text { Gibiyim }\end{array}$} & \multicolumn{2}{|c|}{ 4.Eminim } & \multicolumn{2}{|c|}{$\begin{array}{l}\text { 5. Oldukça } \\
\text { Eminim }\end{array}$} \\
\hline & $\overline{\mathrm{N}}$ & 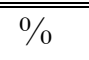 & $\overline{\mathrm{N}}$ & $\bar{~} \%$ & $\overline{\mathrm{N}}$ & 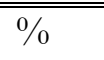 & $\overline{\mathrm{N}}$ & $\%$ & $\overline{\mathrm{N}}$ & \%\% \\
\hline M24 & 1 & 0,9 & - & - & 22 & 20,4 & 48 & 44,4 & 37 & 34,3 \\
\hline M25 & 1 & 0,9 & - & - & 26 & 24,1 & 45 & 41,7 & 36 & 33,3 \\
\hline \multicolumn{11}{|c|}{ DERS SÜRESINDE } \\
\hline M26 & 2 & 1,9 & - & - & 48 & 44,4 & 38 & 35,2 & 20 & 18,5 \\
\hline M27 & 1 & 0,9 & - & - & 44 & 40,7 & 50 & 46,3 & 13 & 12,0 \\
\hline M28 & 1 & 0,9 & - & - & 35 & 32,4 & 46 & 42,6 & 26 & 24,1 \\
\hline M29 & 1, & $\begin{array}{l}0,9 \\
-\end{array}$ & - & - & 19 & 17,6 & 56 & 51,9 & 32 & 29,6 \\
\hline \multicolumn{11}{|c|}{ DERS SONUNDA } \\
\hline M30 & - & - & - & - & 12 & 11,1 & 48 & 44,4 & 48 & 44,4 \\
\hline M31 & 1 & 0,9 & - & - & 25 & 23,1 & 48 & 44,4 & 34 & 31,5 \\
\hline M32 & - & - & - & - & 16 & 14,8 & 44 & 40,7 & 48 & 44,4 \\
\hline
\end{tabular}

Tabloda yer alan değerlere göre ankete katılan öğrencilerin yarıya yakını, sınıf yönetimi süreçleri ile ilgili yeterliklere sahip olduklarına inanmaktadırlar. Bu bağlamda, görüş bildiren öğrencilerden 48 kişi (\% 44,4), derse uygun bir giriş yapabilme konusunda "eminim" derken, 37 kişi (\% 34. 3 ) de "oldukça eminim" diyerek konuyla ilgili görüşlerini ifade etmişlerdir.

Derste ilgi ve dikkat çekme ile ilgili olarak, katılımcıların 45' $\mathrm{i}(\%$ 41,7) “eminim", 36’s1 $(33,3)$ da "oldukça eminim”" cevabını vermişlerdir. 
Sınıf yönetimi ile ilgili süreçlerden biri de ders süresinde yapılanlardır. Ankete katılan öğrencilerden 48 kişi (\% 44. 4) ders sırasında demokratik bir öğrenme ortamının sağlanmasında yeterli olduklarına yeterince inanmadıklarını, 38'i (\% 35. 2) bu konuda yeterli olduklarına inandıklarını, 20 kişisi de $(\%$ 18. 5 ) tamamen inandıklarını ifade etmişlerdir. Öğrencilerin, derse katılımın sürdürülebilir olması ile ilgili ölçek maddesine verdikleri cevaplardan anlaşıldığına göre öğrencilerin çoğunluğu $(\% \quad 46,3)^{\prime} \ddot{u}$ dersin sürdürülmesini sağlayabileceklerine inandıklarını söylemişlerdir. Öğrencilerin yarıya yakını, dersin kesintiye uğratılması durumlarında ve öğrencilerin derse katılımlarını temin etmekte olumlu geri bildirimde bulanabileceklerini beyan etmişlerdir.

Öğrenciler, dersin başında ve sürdürülmesinde olduğu gibi dersin bitirilmesi sürecinde de gerekli öğretmenlik davranışlarını yerine getirebilecekleri ile ilgili güven içinde olduklarını belirtmişlerdir. (Bkz. Tablo 6).

\section{5. İletişim Alt Problemi}

Araştırmanın alt boyutları içinde yer alan problemlerden biri de iletişim alt problemidir. İletişim alt problemi, öğrencilerle etkili iletişim kurabilme, ders sırasında öğrencilere açık ve anlaşılır yönergeler verebilme, konunun işlenişi sırasında öğrencilerin derse katılımını temin etmek ve dersi anlamalarını sağlayacak konuya uygun sorular sorabilmeyi, sözel dili etkili ve anlaşılır bir şekilde kullanabilmeyi, etkili konuşma ve etkin dinleme becerilerine sahip olmayı kapsamaktadır. Ölçekte bu yeterlikleri ölçmek için kullanılan maddeler, 33, 34, 35, 36, 37 ve 38. maddeleridir. Ankete katılan öğrencilerin iletişim alt problemi ile ilgili cevaplarının istatistiksel sonuçları tablo 7 de gösterilmiştir.

Tablo 7. İletişim Alt Problemi İle İlgili Betimsel İstatistikler

\begin{tabular}{|c|c|c|c|c|c|c|c|c|c|c|}
\hline & \multicolumn{2}{|c|}{$\begin{array}{l}\text { 1. Hiç } \\
\text { Emin } \\
\text { Değilim }\end{array}$} & \multicolumn{2}{|c|}{$\begin{array}{l}\text { 2.Emin } \\
\text { Değilim }\end{array}$} & \multicolumn{2}{|c|}{$\begin{array}{l}\text { 3. Emin } \\
\text { Gibiyim }\end{array}$} & \multicolumn{2}{|c|}{ 4.Eminim } & \multicolumn{2}{|c|}{$\begin{array}{l}\text { 5. Oldukça } \\
\text { Eminim }\end{array}$} \\
\hline & $\mathrm{N}$ & $\%$ & $\mathrm{~N}$ & $\%$ & $\mathrm{~N}$ & $\%$ & $\mathrm{~N}$ & $\%$ & $\mathrm{~N}$ & $\%$ \\
\hline M33 & - & - & - & - & 17 & 15,5 & 54 & 50,0 & 37 & 34,3 \\
\hline M34 & - & - & - & - & 25 & 23,1 & 44 & 40,7 & 39 & 36,1 \\
\hline
\end{tabular}




\begin{tabular}{lllllllllll} 
M35 & - & - & - & - & 36 & 33,3 & 32 & 29,6 & 40 & 37,0 \\
M36 & - & - & - & - & 10 & 9,3 & 36 & 33,3 & 62 & 57,4 \\
M37 & 1 & 0,9 & - & - & 30 & 27,8 & 33 & 30,6 & 44 & 40,7 \\
\hline M38 & - & - & - & - & 47 & 43,5 & 36 & 33,3 & 25 & 23,1
\end{tabular}

Örneklem grubunu oluşturan katıllimcılar, iletişim alt problemi ile ilgili ölçek maddelerine verdikleri cevaplara göre, sınıf içi öğretmenlik uygulaması sürecinde, öğrencilerle iletişim kurmakta zorluk çekmeyecekleri kanaatinde olduklarını ifade etmişlerdir. Katılımcı öğrencilerin yarısı (\% 50,0) öğrencilerle etkili iletişim kurabileceklerine inandıklarını belirtirlerken, \% 40’1 anlaşılır açıklamalar ve yönergeler verebileceklerini söylemişlerdir.

İletişim ile ilgili yeterlikler arasında yer alan ve uygulama öğretmeninin derste öğrencilerin konuyu anlamalarını sağlamak ve kalıcı davranış kazanmalarına yardımcı olmak için konuya uygun düşündürücü sorular sorabilme becerileri ile ilgili olarak, orta düzeyde bir yeterlik gerçekleşmiştir. Katılımcıların \% 33. 3'ü bu konuda "emin gibiyim" cevabını verirlerken, \% 29'u “eminim", \% 37'si de "oldukça eminim" cevabını vermişlerdir. Katılımcıların yarıdan fazlası (\% 57, 4) ses tonunu etkili biçimde kullanma becerisi ile ilgili olarak "oldukça eminim" diyerek öz güvenlerini beyan etmişlerdir. Etkili konuşma ile birlikte etkili dinleme becerileri konusunda da öğrencilerin oldukça güven içinde bulundukları gözlenmiştir (Bkz. Tablo 7).

\section{6. Değerlendirme ve Kayıt Tutma Alt Problemi}

Değerlendirme ve kayıt tutma alt problemi ile ilgili olarak öğretmenlik uygulaması ölçeğinin 39 ve 40. maddeleri yer almaktadır. Okul uygulama deneyimi içinde bulunan örneklem grubu öğrencilerinin konu alanı çerçevesinde işlenecek derse uygun değerlendirme materyali ya da formu hazırlayabilme ve öğrencilerin anlama düzeylerine göre geri bildirimde bulunabilme yeterliğini ölçmeyi amaçlamaktadır. 

İstatistiği

Tablo 8. Değerlendirme ve Kayıt Tutma Alt Problemi Betimsel Değerlendirme ve Kayıt Tutma Alt Problemi

\begin{tabular}{|c|c|c|c|c|c|c|c|c|c|c|}
\hline & \multicolumn{2}{|c|}{$\begin{array}{l}\text { 1. Hiç } \\
\text { Emin } \\
\text { Değilim }\end{array}$} & \multicolumn{2}{|c|}{$\begin{array}{l}\text { 2.Emin } \\
\text { Değilim }\end{array}$} & \multicolumn{2}{|c|}{$\begin{array}{l}\text { 3. Emin } \\
\text { Gibiyim }\end{array}$} & \multicolumn{2}{|c|}{ 4.Eminim } & \multicolumn{2}{|c|}{$\begin{array}{l}\text { 5. Oldukça } \\
\text { Eminim }\end{array}$} \\
\hline & $\mathrm{N}$ & $\%$ & $\mathrm{~N}$ & $\%$ & $\mathrm{~N}$ & $\%$ & $\mathrm{~N}$ & $\%$ & $\mathrm{~N}$ & $\%$ \\
\hline M39 & - & - & - & - & 33 & 30,6 & 49 & 45,4 & 26 & 24,1 \\
\hline M40 & - & - & - & - & 24 & 22,2 & 47 & 43,5 & 37 & 34,3 \\
\hline
\end{tabular}

Tabloda görüldüğü gibi ankete katılan öğrencilerden 49 kişi $(\%$ $45,4)$ konuya uygun değerlendirmeyi yapacak materyali hazırlama konusunda emin olduklarını, 47 kişi $(\% \quad 43,5)$ öğrencilerin anlam düzeylerine uygun dönütler verebileceklerine inandıklarını belirtmişlerdir.

\section{Bağımsız İlişkiler Grup t Testi Analiz Sonuçları}

4. 1. Öğretmenlik Uygulaması Ölçeği Alan Eğitimi Alt Problemi Puanlarının Öğrencilerin Cinsiyet Değişkenine Göre Farklılaşıp Farklılaşmadığını Belirtmek Üzere Yapılan Bağımsız Grup t Testi Sonuçları

\section{1. Konu Alanı Alt Problemi}

Tablo 9. Konu Alanı Alt Boyut t Testi Analiz Sonuçları

\begin{tabular}{lllllllllc}
\hline \hline & & \multicolumn{1}{c}{} & & & \multicolumn{4}{c}{ tTesti } \\
\hline \hline Puan & Gruplar & $N$ & $X$ & $s s$ & $S b$ & $t$ & $S d$ & $p$ \\
Konu Alan1 & Kadin & 60 & 3,9208 &, 65982 &, 08518 &,- 392 &, 696 & 04792 \\
\cline { 2 - 9 } Alt Problemi & Erkek & 48 & 3,9688 &, 59391 &, 08572 &,- 396 &, 693 & 04792 \\
\hline
\end{tabular}

Ankete katılan öğrencilerin cinsiyet durumuna göre öğretmenlik uygulaması ile ilgili görüşleri arasındaki farkın bulunup bulunmadığı ile ilgili yapılan bağımsız değişkenler $t$ testi sonuçları tabloda yer almaktadır (Bkz. Tablo 9). Bu verilere göre, cinsiyet değişkeni bağımsız grup t testi sonucunda, grupların aritmetik ortalamaları arasındaki fark, istatistiksel olarak anlamlı bulunmamıstır. $(\mathrm{t}=-, 392, \mathrm{p}<.05)$. 


\section{2. Alan Eğitimi Alt Problemi}

Tablo 10. Alan Eğitimi Alt Problemi Grup T Testi Analiz Sonuçları

\begin{tabular}{lllllllll}
\hline \hline & & & & & \multicolumn{4}{c}{$t$ Testi } \\
\hline Puan & Gruplar & $N$ & $X$ & $s s$ & $S b$ & $t$ & $S d$ & $p$ \\
Alan Eğitimi & Kadın & 60 & 3,8433 &, 50903 &, 06571 &,- 593 &, 555 & 095 \\
\cline { 2 - 9 } Alt Problemi & Erkek & 48 & 3,9000 &, 47401 &, 06842 &,- 597 &, 552 & 094
\end{tabular}

Tabloda görüldüğü gibi, örneklemi oluşturan öğrencilerin öğretmenlik uygulaması Alan Eğitimi Alt Problemi puanlarının öğrencinin cinsiyeti değişkenine göre anlamlı bir farklılık gösterip göstermediğini belirlemek amacıyla gerçekleştirilen bağımsız grup $t$ testi sonucunda, grupların aritmetik ortalamaları arasındaki fark, istatistiksel olarak anlamlı bulunmamıştır. $(\mathrm{t}=-, 593 \mathrm{p}<.05)$.

\section{3. Öğretme ve Öğrenme Süreci Alt Problemi}

Tablo 11. Öğretme ve Öğrenme Süreci Alt Boyut t Testi Analiz Sonuçları

\begin{tabular}{cccccccccc}
\hline \hline & & & & & & \multicolumn{3}{c}{$t$ Testi } \\
\hline \hline Puan & Gruplar & $N$ & $X$ & $s s$ & $S b$ & $t$ & $S d$ & $p$ \\
Konu Alanı & Kadın & 60 & 3,9560 &, 53567 &, 53567 &,- 498 &, 620 &, 10345 \\
\cline { 2 - 9 } Alt Problemi & Erkek & 48 & 4,0074 &, 53233 &, 53233 &,- 498 &, 620 &, 10337
\end{tabular}

Tablo incelendiğinde örneklemi oluşturan öğrencilerin öğretmenlik uygulaması öğretme öğrenme süreci Alt Problemi puanlarının, öğrencinin cinsiyet değişkenine göre aralarındaki fark, istatistiksel olarak anlamlı bulunmamıstır. $(\mathrm{t}=-, 498, \mathrm{p}<.05)$.

\section{4. Sınıf Yönetimi Alt Problemi}

\begin{tabular}{lllllllll}
\hline \hline & & \multicolumn{1}{c}{} & \multicolumn{1}{c}{ Testi } \\
\hline \hline Puan & Gruplar & $N$ & $X$ & $s s$ & $S h$ & $t$ & $S d$ & $p$ \\
Konu Alani & Kadin & 60 & 3,9574 &, 51229 &, 123 & $-1,556$ &, 095 &, 09582 \\
\cline { 2 - 9 } Alt Problemi & Erkek & 48 & 4,1065 &, 47194 &, 119 & $-1,570$ &, 620 &, 09494 \\
\hline
\end{tabular}


Tabloda görüldüğü gibi, örneklemi oluşturan öğrencilerin öğretmenlik uygulaması Sınıf Yönetimi Alt Problemi puanlarının öğrencinin cinsiyeti değişkenine göre bağımsız grup $\mathrm{t}$ testi sonucunda, grupların aritmetik ortalamaları arasında anlamlı bir fark bulunmamıştır. $(\mathrm{t}=-1,556, \mathrm{p}<.05)$.

\section{5. Öğretmenlik Uygulaması Ölçeği İletişim Alt Problemi}

Tablo 12. İletişim Alt Boyut $t$ Testi Tablosu

\begin{tabular}{lllllllll}
\hline \hline & & & & & & \multicolumn{3}{c}{$t$ Testi } \\
\hline Puan & Gruplar & $N$ & $X$ & $s s$ & $S b$ & $t$ & $S d$ & $p$ \\
Konu Alan1 & Kadin & 60 & 4,0778 &, 61331 &, 393 &,- 858 &, 123 &, 09582 \\
\cline { 2 - 9 } Alt Problemi & Erkek & 48 & 4,1771 &, 57674 &, 389 &,- 864 &, 119 &, 09494 \\
\hline
\end{tabular}

Tabloda görüldüğü gibi, örneklemi oluşturan öğrencilerin öğretmenlik uygulaması İletişim Alt Problemi puanlarının öğrencinin cinsiyeti değişkenine göre anlamlı bir farklllık gösterip göstermediğini belirlemek amaciyla gerçekleştirilen bağımsız grup $\mathrm{t}$ testi sonucunda, gruplar arasinda anlamlı bir fark yoktur $(\mathrm{t}=-1,556, \mathrm{p}<.05)$.

\section{6. Değerlendirme ve Kayıt Tutma Alt Problemi}

Tablo 13. Değerlendirme ve Kayıt Tutma Alt Boyut t Testi Tablosu

\begin{tabular}{llllllllll}
\hline \hline & & & & & & \multicolumn{3}{c}{$t$ Testi } \\
\hline \hline Puan & Gruplar & $N$ & $X$ & $s s$ & $S b$ & $t$ & $S d$ & $p$ \\
Konu Alanı & Kadın & 60 & 3,9667 &, 64352 &, 278 & $-1,091$ &, 278 &, 12605 \\
\cline { 2 - 9 } Alt Problemi & Erkek & 48 & 4,1042 &, 66010 &, 279 & $-1,089$ &, 279 &, 12641 \\
\hline
\end{tabular}

Tabloda da görüldüğü gibi örneklemi oluşturan öğrencilerin öğretmenlik uygulaması değerlendirme ve Kayıt Tutma Alt Problemi puanlarının öğrencinin cinsiyeti değişkenine göre bağımsız grup $t$ testi sonucunda, grupların aritmetik ortalamaları arasındaki fark istatistiksel olarak anlamlı bulunmamıştır. ( $\mathrm{t}=-1,091, \mathrm{p}<.05)$. 


\section{Sonuç ve Öneriler}

Öğretmenlik uygulaması dersi, öğretmen adayları için hizmet öncesi dönemde öğretmenlik mesleğini bilişsel, duyuşsal ve davranışlar yönünden deneyimleme firsatı veren derslerden biridir. Mezuniyet sonrası dönemde, öğretmen olarak görev almak isteyen öğrencilerin, öğretmenlik mesleği ile ilgili motivasyonunu geliştirmeye katkı sağladığı gibi cesaret kırıcı ve olumsuz etkileri de olabilmektedir.

Öğretmenlik Uygulaması dersi, uzun sayılabilecek bir teorik eğitim sürecinin içinden gelen öğretmen adaylarını, öğrencilik rolünden çıkarıp, öğretmenlik rolüne girmelerini sağlayan yaşantı alanıdır. Öğretmen adayı öğrencilerin, neredeyse ilk defa öğrencilerle yüz yüze deneyim yaşayacak olmaları onların, bu süreci yönetmelerinde kaygılı olmalarına neden olabilmektedir. Öğretmenlik uygulaması için ilk ve orta öğretim kurumlarına giderek, sınıf içinde ya da okul bahçesinde, öğrencilerle karşılaşacak olmaları, onları uygun tepkileri verebilmek konusunda tedirgin etmektedir. Özellikle sınıf içi öğretmenlik deneyimi sırasındaki öğretim sürecinin yönetimi konusundaki deneyimsizlikler, öğrenci grubu ile ilgili uygun iletişim kurup, kuramama ile ilgili belirsizlikler, öğrencilerin uygulama yapma ile ilgili cesaretinin kırılmasına neden olmaktadir.

Her türlü kayg1 ve heyecan yönetiminde olduğu gibi öğretmenlik uygulaması ile ilgili oluşan kayg1 ve heyecanın yönetilebilir olmasında adayların kendilerine güvenmeleri bu kayg1 durumu ile başa çıkmada önemli bir yeterliktir.

Öğretmenlik uygulaması ile ilgili sürecin yönetilmesinde gerekli olan bilgi, beceri ve davranışlar konusunda yeterli olmak öğrencilerde meydan gelen muhtemel kayg1 durumlarının yönetilmesine yardımc1 olacaktır.

Dokuz Eylül Üniversitesi İlahiyat Fakültesi son sınıf öğrencilerinin öğretmenlik uygulaması ile ilgili özgüven durumlarını öğrenmek için yapılan bu araştırmada varılan sonuçları şöyle sıralamak mümkündür:

1. Yapılan araştırmada elde edilen veriler, örneklem grubu öğrencilerinin konu alanı ile ilgili bazı eksikliklerin olduğunu ortaya koymaktadır. Ayrıca öğrencilerin, cinsiyet durumuna göre öğretmenlik 
uygulaması ile ilgili görüşleri arasındaki farkın bulunup bulunmadığ1 ile ilgili yapılan bağımsız değisskenler $t$ testi sonuçlarına göre, cinsiyet değişkeni bağımsız grup $t$ testi sonucunda, grupların aritmetik ortalamaları arasındaki fark istatistiksel olarak anlamlı bulunmamıştır. $(\mathrm{t}=$ $-, 392, \mathrm{p}<.05)$.

2. Öğretmenlik uygulaması sürecinde öğrencilerin dersi başlatma, sürdürme ve ders sırasında önceden planlanan kazanımları gerçekleştirmek için gerekli olan yeterlikler arasında "Alan Eğitimi Yeterliğı”" gelmektedir. Araştırmaya göre öğrencilerin alan eğitimi ile ilgili olarak sınıf içi ders uygulamasını yapabilecek öz güvene sahip oldukları anlaşılmaktadır. Öğrencilerin sahip oldukları bu özgüven, her iki erkek ve kız, her iki cinsiyette de aynı şekilde bulunmaktadır. Nitekim örneklem grubunu oluşturan katılımcılar ile ilgili yapılan t testi analizinde cinsiyet değişkenine göre anlamlı bir farklılık gösterip göstermediğini belirlemek amacıyla gerçekleştirilen bağımsız grup $t$ testi sonucunda, grupların aritmetik ortalamaları arasındaki fark istatistiksel olarak anlamlı bulunmamıstır. ( $\mathrm{t}=-, 593 \mathrm{p}<.05)$.

3. Ankete katılan öğrencilerin, öğretme ve öğrenme sürecinde yapılması gereken planlama, uygulama ve gerekli olan yöntem ve teknikleri seçme ve kullanma konusunda yeterli olduklarına inandıkları görülmüştür. Bununla birlikte gerek planlama ve gerekse öğretme ve öğrenme süreci ile ilgili konularda deneyim eksikliğinden kaynaklanan bazı tereddütlerinin olduğu da tespit edilmiştir. Diğer yandan öğrenme ve öğretme süreci ile ilgili olarak cinsiyet bağımsız değişkeni bakımından istatistiksel olarak anlamlı bir fark yoktur. $(\mathrm{t}=-, 498, \mathrm{p}<.05)$.

4. Ankete katılan öğrenciler derse katılımın sürdürülebilir olması ile ilgili olarak güven içindedirler. Dersin kesintiye uğratılması durumlarında ve öğrencilerin derse katılımlarını temin etmek bakımından olumlu geri bildirimde bulanabilmek ile ilgili konularda gerekli olan öz güvene sahiptirler. Öğrenciler, dersin başında ve sürdürülmesinde olduğu gibi dersin bitirilmesinde gerekli öğretmenlik davranışlarını yerine getirebileceklerine inanmaktadırlar.

Sınıf yönetimi ile ilgili bağımlı değişken sonuçları, cinsiyet bağımsız değişkeni bakımından da $t$ testi analizine tabi tutulmuştur. Söz konusu testin sonucuna göre ankete katılan öğrencilerin sınıf yönetimi ile ilgili görüşlerinin cinsiyet bağımsız değişkeni bakımından aralarında istatistiksel olarak anlamlı bir fark bulunmamıştır. $(\mathrm{t}=-1,556, \mathrm{p}<.05)$. 
5. Örneklem grubu öğrencileri, öğretmenlik uygulaması deneyimleme sürecinde, sınıf içinde ve sınıf dişında öğrenci grupları ile gerekli olan etkili iletissim kurma ve etkin dinleme becerilerine sahip olduklarına inanmaktadırlar. İletişim ile ilgili bağımlı değişkenlerin puanlarının, öğrencinin cinsiyeti değişkenine göre aralarında anlamlı bir farklılık gösterip göstermediğini belirlemek amacıyla gerçekleştirilen bağımsız grup t testi sonucunda, gruplar arasında anlamlı bir fark tespit edilmemiştir $(\mathrm{t}=-1,556, \mathrm{p}<.05)$.

6. Okul uygulama deneyimi içinde bulunan örneklem grubu öğrencilerinin konu alanı çerçevesinde işlenecek derse uygun değerlendirme materyali ya da formu hazırlayabilme ve öğrencilerin anlam düzeylerine göre geri bildirimde bulunabilme yeterliğine sahip oldukları anlaşılmaktadır.

\section{Öneriler}

Yapılan araştırmada elde edilen bulgular ve analizlerin neticesinde öğretmenlik uygulamasının istenilen düzeyde ve verimli bir şekilde gerçekleştirilmesi için bazı tekliflerde bulunmak yararlı olacaktır. Bu teklifler şunlardır:

1. Öğretmenlik mesleğinin yüksek düzeyde motivasyon isteyen, isteyerek yapılması gereken bir meslek olduğu bilincinin geliştirilmesi gerekmektedir.

2. Öğretmenlik mesleğinin uygulama ağırlıklı bir meslek olduğu anlayışının yerleştirilmesi için sınıf içi atölye çalışmalarına ve mikro eğitim uygulamalarına ağırlık verilmelidir.

3. Öğrencilere yeterlik kazandırmak için alanla ilgili bilgileri artırmak yerine konuya uygun bilgileri seçme ve kullanma becerilerinin geliştirilmesine yönelik çalışmalar yapılmasına önem verilmelidir.

4. Sınıf yönetimi ve zaman yönetimi konularında öğrencilerle işbirliği yapmak, birlikte etkinlikler oluşturmak konularında uygulamaya başlamadan önce ara sınıflarda, sık sık sınıf içi deneyimler ve etkinlikler yapılmalıdır.

5. Öğrencilerle etkili iletişim kurma ve etkin dinleme becerilerini geliştirici kurslar ve seminerler tertip edilmelidir. $\mathrm{Bu}$ bağlamda 
"Diksiyon”, “Etkili Dinleme”, “ İkna İletişimi” ve "Çatışma Yönetimi”” konularında yeterlik kazandırılmalıdır. 


\section{KAYNAKÇA}

Acuner, Hac1 Yusuf. "İlahiyat Fakültesi Öğrencilerinin Din Görevliliği Mesleğine Yönelik Tutumları", Uluslararası Sosyal Arastırmalar Dergisi (2016): 2306-2315.

Akyüz, Yahya.. "Türk Eğitim Tarihi". Ankara Üniversitesi Eğitim Bilimleri Fakültesi Yayınları. (1997)

Benjamin, S. Bloom. Insan Nitelikleri ve Okulda Öğrenme. Pegem Yayınc1lik. (2012)

Bulut, İlhami.. "Öğretmen Adaylarının Öğretmenlik Mesleğine İlişkin Tutumlarının Değerlendirilmesi" . Dicle Üniversitesi Ziya Gökalp Eğitim Fakültesi Dergisi, (2009): 13-24.

Can, Niyazi. "Öğretmen ve Yöneticilerin Etkinliğinin Öğretimdeki Rolü" Kuram ve Uygulamada Ë̈itim Yönetimi , (1998):1-15.

Çiçek, Şeref, \& İnce, M. Levent. "Öğretmen Adaylarının Öğretmenlik Uygulams1 Sürecine İlişkin Görüşleri". Spor Bilimleri Dergisi, (2005): 146-155.

Demir, Özden \& Çamlı, Özgül. "Öğretmenlik Uygulaması Dersinde Uygulama Okullarında Karşılaşılan Sorunların Sınıf ve Okul Öncesi Öğretmenliği Öğrenci Görüşleri Çerçevesinde İncelenmesi: Nitel Bir Çalışma ". Uludăg Üniversitesi Eğitim Fakültesi Dergisi, (2011): 117-139.

Dursunoğlu, H. "Cumhuriyet Döneminde İlköğretime Öğretmen Yetiştirmenin Tarihi Gelişimi" . Milli Ĕgitim Dergisi, (2003):64-74.

Erden , Münire. Eğitim Bilimine Girişs. Ankara: Arkadaş Yayın Dağıtım. (2013).

Görgen, İzzet., Çokçalışkan, Halil, \& Korkut, Ünsal. "Öğretmenlik Uygulaması Dersinin Öğretmen Adayları Uygulam Öğretmenleri ve Uygulama Öğretim Üyeleri Açısından İşlevselliği". Muğla Üniversitesi Sosyal Bilimler Enstitüsü Dergisi , (2012).56-72.

Karadüz , Adnan., Eser, Yusuf., Şahin , C.emil, \& İlbay, Azmi." Eğitim Fakültesi Son Sinıf Öğrencilerinin Görüşlerine Göre Öğretmenlik Uygulaması Dersinin Etkinlik Düzeyi." Mustafa Kemal Üniversitesi Sosyal Bilimler Enstitüsü Dergisi , (2009):442-455. 
Kılıç, Durmuş."Öğretmenlik Uygulaması Dersinin Öğretmen Adayları Üzerine Etkisinin Değerlendirilmesi" . Kažm Karabekir Eğitim Fakültesi Dergisi , (2004):172-184.

Köse , Meliha., \& Ebru , Demir. "Öğretmenlerin Rol Modelliği Hakkında Öğrenci Görüşleri." Uluslararası Sosyal ve Ekonomik Bilimler Dergisi, (2014): 1-18.

MEB. (2018). Öğretmenlik Starateji Belgesi. Ankara: Milli Eğitim Bakanlığı.

Nayır, F., \& Çınkır, Ş. "Uygulama Öğretmenleri, Yöneticileri ve Pedagojik Formasyon Öğrencilerinin Okullarda Öğretmenlik Uygulamasında Karşılaştıkları Sorunlar ve Çözüm Önerileri." Uluslararası Eğitim Programları ve Öğretim Çalısmaları Dergisi, (2014): 71-86.

Şeyihoğlu, Ayşegül., \& Duman, Neşe. "Özel Öğretim Yöntemleri Dersinin Pedagojik Formasyon Eğitimi Çoğrafya Bölümü Öğrencileri Açısından Bakış". Kastamonu Eğitim Dergisi, (2020: 442-456.

Şimşek, Selçuk., Alkan, Vesile., \& Erdem, Ali Rıza. "Öğretmenlik Uygulamsına İlişkin Nitel Bir Araştırma ". Pamukekale Üniversitesi Ë̆itim Fakültesi Dergisi, (2013): 63-73.

Ünver, Gülsen. "Öğretmenlik Uygulamasında İşbirliği : Bir Durum Çalışması". Gað̧i Üniversitesi Eğitim Fakültesi Dergisi , (2003): 87100.

Üstüner, Mehmet. "Geçmişten Günümüze Türk Eğitim Sisteminde Öğretmen Yetiştirme ve Günümüz Sorunları". Inönü Üniversitesi Eg̈itim Fakültesi Dergisi, (2004):63-82.

Yılmaz, Muamber. "Sınıf Öğretmeni Adaylarının Öğretmenlik Uygulamsı Dersini Yürüten Öğretim Elemanlarına İlişkin Görüşleri". Gað̧iantep Üniversitesi Sosyal Bilimler Dergisi , (2011):1377-1387.

YÖK. (2020, 06 08). Yüksek Öğretim Kurulu. yok.gov.tr: https://istatistik.yok.gov.tr/ adresinden alınd

YÖK (2020, 05 31). Yüksek Öğretim Kurulu. yok.gov.tr: https://www.yok.gov.tr/Sayfalar/Kurumsal/IdariBirimler/egiti m_ogretim_daire_bsk/pedogojik_formasyon_egitim_programi.a spx adresinden alind 1 